\title{
PENGARUH PENGGUNAAN MULTIMEDIA INTERAKTIF TERHADAP PENGUASAAN KONSEP DAN KETERAMPILAN BERPIKIR KRITIS SISWA PADA MATERI SUHU DAN KALOR
}

\author{
Sadam Husein ${ }^{1}$, Lovy Herayanti ${ }^{1}$, Gunawan ${ }^{2}$ \\ 1) Program Studi Pendidika Fisika \\ 2) Program Studi Pendidika Fisika FKIP \\ Universitas Mataram \\ Mataram, Indonesia \\ Email: sadamhusein7991@gmail.com
}

\begin{abstract}
This research aims to know the effect of using interactive multimedia towards concepts mastery and critical thinking skill of students on the material of temperature ang heat. This research is an experimental research that uses pretest-posttest control design. The sample of this research is grade XA and XB students of SMAN 1 Alas in the academic year 2013/2014 that determined by cluster random sampling technique. The instruments that used to collect the data are test sheets of mastering concepts is developed based on indicator of temperature and heat learning material on the sub topic of expansion, heat transfer and black principle. Meanwhile, the test of critical thinking skill is developed based on the indicator of argument analysis shows that mean score of concepts mastery of experimental group is $61 \%$ and control group is $54 \%$. The result of $\mathrm{t}$-test of concepts mastery and critical thinking skill shows that experimental group is significantly higher that control group. It means that the use of interactive multimedia has an effect towards concepts mastery and critical thinking skill of students on the material of temperature and heat.
\end{abstract}

Keywords: multimedia interaktif, penguasaan konsep, keterampilan berpikir kritis, suhu dan kalor.

\section{Pendahuluan}

Pembelajaran fisika merupakan bagian dari sains yang syarat dengan konsep-konsep abstrak. Karakteristik fisika tersebut diharapkan dapat dimanfaatkan untuk membiasakan dan mengembangkan keterampilan berpikir dasar siswa menuju pada keterampilan berpikir tingkat tinggi. Keterampilan berpikir tingkat tinggi merupakan suatu keterampilan berpikir yang tidak hanya membutuhkan keterampilan mengingat saja, namun membutuhkan keterampilan lain yang lebih tinggi, seperti keterampilan berpikir kritis. Keterampilan berpikir kritis secara esensial merupakan keterampilan menyelsaikan masalah (problem solving). Menurut Paul dan Elder (2007), berpikir kritis merupakan cara bagi seseorang untuk meningkatkan kualitas dari hasil pemikiran menggunakan teknik sistemasi cara berpikir dan menghasilkan daya pikir intelektual dalam ide-ide yang digagas.

Model pembelajaran fisika yang dikembangkan oleh kebanyakan guru sering tidak menyiapkan siswa untuk terlibat dalam upaya penggunaan dan pengembangan pola berpikir dasar menuju pada pola berpikir tingkat tinggi. Penguasaan konsep dan keterampilan berpikir kritis siswa terhadap konsep- konsep fisika sebagai indikator keberhasilan suatu proses belajar mengajar dari berbagai penelitian secara umum masih kurang.

Kurangnya penguasaan konsep-konsep fisika dan keterampilan berpikir kritis salah satunya disebabkan karena siswa tidak banyak dilibatkan dalam proses pengkonstruksian suatu konsep dalam pikirannya. Untuk dapat mengembangkan pengusaan konsep dan keterampilan berpikir kritis pada pembelajaran konsep-konsep fisika yang bersifat abstrak perlu bantuan teknologi informasi. Teknologi informasi dalam pendidikan diaplikasikan dalam bentuk multimedia interaktif berupa perangkat lunak (software), yang memberikan fasilitas kepada siswa untuk mempelajari suatu materi. Penggunaan aplikasi multimedia interaktif dalam pembelajaran akan meningkatkan efisiensi, motivasi, serta memfasilitasi belajar aktif, belajar eksperimental, konsisten, dengan belajar yang berpusat pada siswa (Exline, 2004).

Pengunaan multimedia interaktif dalam pembelajaran juga sangat memungkinkan untuk meningkatkan kemampuan berpikir yang diharapkan. Secara umum manfaat yang dapat diperoleh melalui pengunaan multimedia interaktif adalah proses pembelajaran dapat berjalan lebih menarik, lebih interaktif, jumlah waktu mengajar dapat dikurangi, 
kualitas belajar siswa dapat ditingkatkan dan proses belajar mengajar dapat dilakukan dimana dan kapan saja, serta dapat meningkatkan kemampuan penalaran siswa, Heinich (1996) dalam Sutarno (2011).

M. Sutarno dan Desi. H. P. (2012), dengan penelitian tentang multimedia interaktif menemukan bahwa bahwa peningkatan penguasaan konsep mahasiswa yang mengikuti pembelajaran menggunakan kelompok belajar berciri kooperatif berbantuan multimedia interaktif secara signifikan lebih tinggi dibandingkan dengan mahasiswa yang mengikuti yang mengikuti pembelajaran konvensional. M. Sutarno (2011), menemukan bahwa peningkatan penguasaan konsep dan keterampilan berpikir kritis mahasiswa yang mengikuti pembelajaran medan magnet mengunakan online interactive multimedia secara signifikan lebih tinggi dibandingkan dengan mahasiswa yang mengikuti pembelajaran konvensional. Selanjutnya Gunawan (2011) menunjukkan bahwa penggunaan multimedia interaktif juga terbukti meningkatkan kemampuan mahasiswa dalam menarik kesimpulan dan memecahkan masalah.

Berdasarkan latar belakang dan beberapa hasil penelitian seperti yang diuraikan di atas, kiranya perlu dilakukan pengembangan pembelajaran dengan memanfaatkan multimedia interaktif. Selanjutnya, akan diselidiki bagaimana pengaruh penggunaan multimedia interaktif terhadap penguasaan konsep dan keterampilan berpikir kritis siswa.

\section{TinjauAn Pustaka}

Menurut Yudhi Munadi (2012), Ada beberapa kelebihan dan kekurangan multimedia interaktif sebagai media pembelajaran diantaranya: (1) Kelebihan multimedia interaktif yaitu: (a) Interaktif artinya Program multimedia ini diprogram atau dirancang untuk dipakai oleh siswa secara individual (belajar mandiri), (b) Memberikan iklim afeksi secara individual artinya yang lebih bersifat afektif dengan cara yang lebih individual, tidak pernah lupa, tidak pernah bosan, sangat sabar dalam menjalankan intruksi, seperti diinginkan, (c) Meningkatkan motivasi belajar (d) Memberikan umpan balik (respon) dan (e) Karena multimedia interaktif diprogram untuk pembelajaran mandiri, maka kontrol pemanfaatannya sepenuhnya berada pada penggunanya. Sedangkan, (2) Kekurangan multimedia interaktif yaitu: (a) Pengembangannya memerlukan adanya tim yang profesional dan (b) Pengembangannya memerlukan waktu yang cukup lama.

Pemanfaatan teknologi multimedia sebagai metode pembelajaran interaktif, merupakan salah satu sarana pembelajaran bagi mahasiswa/siswa, mempunyai beberapa kekuatan dasar, seperti yang dikemukakan oleh Phillips (1997) dalam Hasrul (2010), yaitu: (1) Mixed. Media dengan menggunakan teknologi multimedia, berbagai media konvensional yang ada dapat diintegrasikan ke dalam satu jenis media interkatif, seperti media teks (papan tulis), audio, video, yang jika dipisahkan akan membutuhkan lebih banyak media. (2) User control. Teknologi implimentasi multimedia interaktif (IMMI), memungkinkan pengguna untuk menelusuri materi ajar, sesuai dengan kemampuan dan latar belakang pengetahuan yang dimilikinya, disamping itu menjadikan pengguna lebih nyaman dalam mempelajari isi media, secara berulang-ulang. (3) Simulasi dan visualisasi. Simulasi dan visualisasi merupakan fungsi khusus yang dimiliki oleh multimedia interaktif, sehingga dengan teknologi animasi, simulasi dan visualisasi komputer, pengguna akan mendapatkan infromasi yang lebih nyata dari infromasi yang bersifat abstrak. Dalam beberapa kurikulum dibutuhkan pemahaman yang kompleks, abstrak, proses dinamis dan mikroskopis, sehingga dengan simulasi dan visualisasi peserta didik akan dapat mengembangkan mental model dalam aspek kognitifnya. (4) Gaya belajar yang berbeda. Multimedia interaktif mempunyai potensi untuk mengakomodasi pengguna dengan gaya belajar yang berbeda-beda.

\section{Metode Penelitian}

Jenis penelitian adalah penelitian eksperimen yang dilakukan menggunakan desain Pretest-posttest control group design (Sugiyono, 2012) seperti yang ditunjukan pada tabet 1 berikut ini:

Tabel 1. Desain Penelitian

\begin{tabular}{lcccccc}
\hline \multicolumn{1}{c}{ Kelas } & \multicolumn{2}{c}{ Desain } & Perlakuan & Awal & Akhir \\
\hline Eksperimen & $\mathrm{O}_{1}$ & $\mathrm{X}_{1}$ & $\mathrm{O}_{2}$ & $\mathrm{X}_{1}$ & $\mathrm{Ya}$ & Ya \\
\hline Kontrol & $\mathrm{O}_{3}$ & $\mathrm{X}_{2}$ & $\mathrm{O}_{4}$ & $\mathrm{X}_{2}$ & $\mathrm{Ya}$ & $\mathrm{Ya}$ \\
\hline
\end{tabular}

Keterangan: 
$\mathrm{X}_{1}=$ Menggunakan multimedia interaktif.

$\mathrm{X}_{2}=$ Menggunakan pembelajaran konvensional

Penelitian ini dilaksanakan di SMA Negeri 1 Alas. Sampel dalam penelitian ini adalah kelas $X_{A}$ sebagai kelas eksperimen dan kelas $\mathrm{X}_{\mathrm{B}}$ sebagai kelas kontrol. Data dikumpulkan menggunakan intrumen tes berupa soal penguasaan konsep dan keterampilan berpikir kritis yang telah diuji tingkat validitas, dan reliabilitasnya. Tehnik penggolaan data dengan menggunakan analisis deskriptif dan statistik. Peningkatan hasil tes awal dan tes akhir penguasaan konsep dan keterampilan berpikir kritis siswa dihitung menggukan rumus gain ternormalisasi (N-gain) (Meltzer, 2002) dalam (Muh.Tawil, 2012:4).

$$
g=\frac{S_{\text {post }}-S_{\text {pre }}}{S_{\text {maks }}-S_{\text {pre }}}
$$

Dalam hal ini menyatakan skor tes akhir; menyatakan skor tes awal, dan menyatakan skor maksimum. Kriteria tingkat N-gain dapat dilihat pada tabel 2 berikut ini

\begin{tabular}{cc}
\multicolumn{2}{c}{ Tabel 2 Kategori Tingkat N-Gain } \\
\hline Batasan & Kategori \\
\hline $\mathrm{g}>0,7$ & Tinggi \\
$0,3 \leq \mathrm{g} \leq 0,7$ & Sedang \\
$\mathrm{g}<0,3$ & Rendah \\
\hline
\end{tabular}

Perbandingan serata N-gain antara kelas eksperimen dan kelas kontrol diuji menggunakan uji t pada taraf signifikan 5\% setelah melalui uji normalitas dan homogenitas varian data.

\section{Hasil dan Pembahasan}

\section{A. Hasil}

\section{Data Penguasaan Konsep Kelas Eksperimen dan Kontrol}

Adapun gambar histogram data penguasaan konsep setiap sub materi siswa kelas eksperimen dan kelas kontrol antara lain:

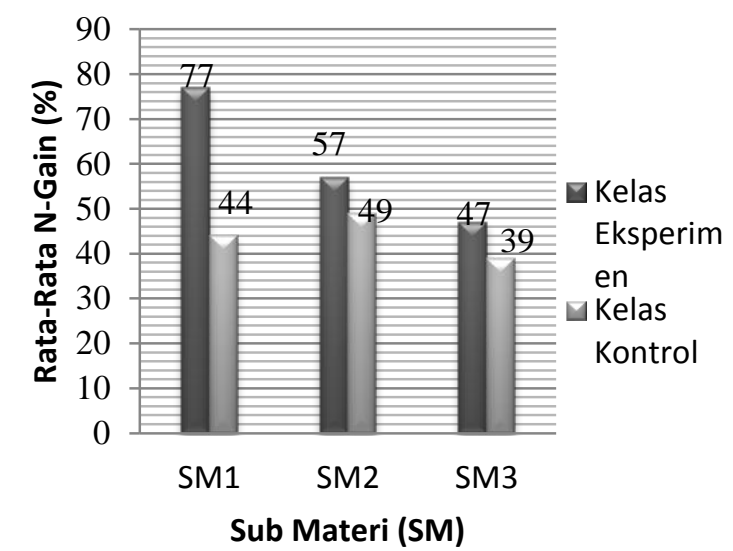

Keterangan: SM1= Pemuaian; SM2=Perpindahan

Kalor; SM3=Asas Black

Gambar 1. Data penguasaan konsep setiap sub materi siswa kelas eksperimen dan kelas kontrol

\section{Data Keterampilan Berpikir Kelas Eksperimen dan Kelas Kontrol}

Gambar histogram data keterampilan berpikir kritis setiap indikator kelas eksperimen dan kelas kontrol adalah sebagai berikut:

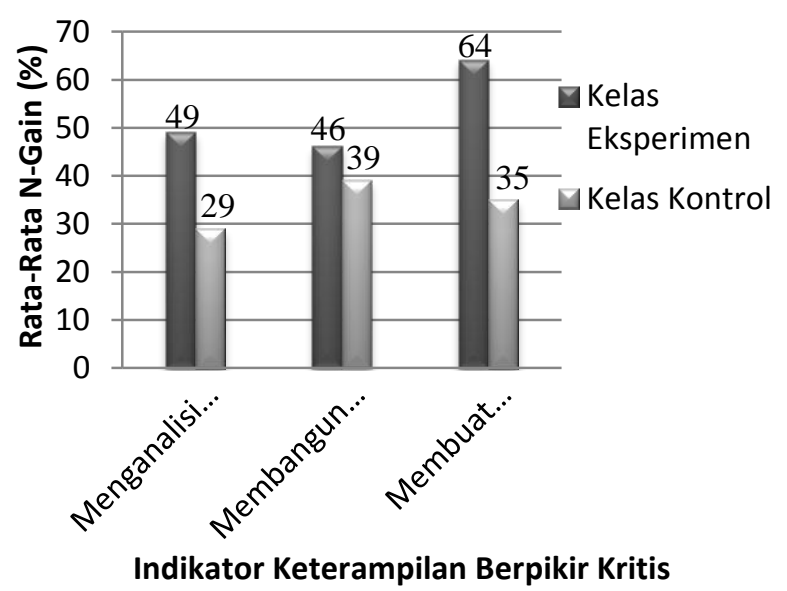

Gambar 2. Data keterampilan berpikir kritis setiap indikator antara kelas eksperimen dan kelas kontrol

\section{B. Pembahasan}

Dalam Penelitian ini data yang dikumpulkan disesuaikan dengan keperluan analisis, yakni analisis penguasaan konsep dan keterampilan berpikir kritis siswa pada materi suhu dan kalor yang diajarkan menggunakan multimedia interaktif pada kelas eksperimen, dengan penguasaan konsep dan 
keterampilan berpikir kritis siswa yang diajarkan tanpa menggunakan multimedia interaktif pada kelas kontrol. Berikut akan dipaparkan hasil penelitian pengaruh pengunaan multimedia interaktif terhadap penguasaan konsep dan keterampilan berpikir kritis pada siswa kelas X-A dan X-B SMAN 1 Alas.

\section{Pengaruh multimedia interaktif terhadap penguasaan konsep}

Materi suhu dan kalor dalam penelitian ini yang dibahas terdiri dari tiga sub materi yaitu pemuaian, perpindahan kalor dan asas black. Perolehan rata-rata $\mathrm{N}$-gain untuk kelas eksperimen sebesar $61 \%$ dan kelas kontrol sebesar $44 \%$. Rata-rata N-gain untuk kelas eksperimen dan kelas kontrol termasuk dalam kategorikan sedang. Berdasarkan data tersebut terlihat dalam kategori yang sama namun rata-rata $\mathrm{N}$-gain untuk kelas eksperimen lebih tinggi dibandingkankan rata-rata $\mathrm{N}$-gain kelas kontrol.

Hasil perbandingan rata-rata $\mathrm{N}$-Gain penguasaan konsep pada kelas eksperimen dan kelas kontrol untuk setiap sub materi, didapatkan rata-rata N-Gain terbesar diperoleh pada sub materi pemuaian sedangkan $\mathrm{N}$-gain terkecil kedua kelas tersebut diperoleh pada sub materi asas black. Hal ini diduga karena karekteristik setiap sub materi yang akhirnya berpengaruh terhadap penyampaian materi dalam multimedia interaktif yang digunakan. Sub materi asas black merupakan materi yang berisi penurunan rumus matematis yang rumit dibangdingkan dengan sub materi yang lainnya. Sebagian besar yang disampaikan pada pertemuan ke tiga membutuhkan prasyarat pemahaman dari materimateri yang disampaikan pada pertemuan sebelumnya, juga dibutuhkan pengetahuan terhadap hukum-hukum asas black dan prinsip atau kaedah-kaedah fisika yang berkaitan dengan suhu dan kalor. Selain itu juga sulitnya membuat atau menampilkan multimedia interaktif. Akibatnya, multimedia interaktif yang berhasil digunakan dalam proses pembelajaran pada materi asas black merupakan simulasi sederhana yang secara signifikan kurang memberikan gain yang baik terhadap penguasaan konsep pada asas black. Multimedia interaktif yang digunakan pada materi asas black adalah simulasi asas black yang menunjukkan pelepasan dan penerimaan kalor suatu zat cair dan zat padat. Simulasi ini diduga kurang menunjang terhadap pemahaman konsep siswa dalam hal menetukan bessarnya kalor yang dilepas maupun kalor yang diterima. Hal inilah yang diduga menjadi penyebab rendahnya $\mathrm{N}$-gain yang diperoleh siswa pada sub materi asas black. Meskipun demikian berdasarkan analisis data diperoleh bahwa $\mathrm{N}$-gain sub materi asas black siswa eksperimen lebih tinggi dibandingkan kelas kontrol.

Berdasarkan hasil uji $\mathrm{t}$ diperoleh hasil bahwa terdapat perbedaan yang signifikan antara peningkatan penguasaan konsep kelas eksperimen dan kelas kontrol dengan nilai $t_{\text {hitung }}=2,8>t_{\text {tabel }}=1,671$, hal ini menunjukkan bahwa penggunaan multimedia interaktif lebih efektif dalam meningkatkan penguasaan konsep dari pada pembelajaran tanpa multimedia intkonvensional. Adanya peningkatan hasil pembelajaran setelah penggunaan multimedia interaktif menunjukkan bahwa adanya pengaruh penggunaan multimedia interaktif terhadap penguasaan konsep pada materi suhu dan kalor.

\section{Pengaruh penggunaan multimedia interaktif terhadap keterampilan berpikir kritis}

Indikator keterampilan berpikir kritis yang digunakan dari beberapa indikator keterampilan berpikir kritis menurut Ennis (1985) dalam Yulianti (2012), yaitu menganalisis argument, membangun keterampilan dasar dan membuat inferensi. Hasil tes awal dan tes akhir keterampilan berpikir kritis tersebut menghasilkan $\mathrm{N}$-gain kelas eksperimen sebesar 66\% dan kelas kontrol sebesar 54\% Rata-rata N-gain untuk kelas eksperimen dan kelas kontrol termaksud kategori sedang. Berdasarkan data tersebut terlihat bahwa ratarata $\mathrm{N}$-gain untuk kelas eksperimen lebih tinggi dari pada kelas kontrol.

Hasil analisis data menunjukkan bahwa keterampilan berpikir kritis pada indikator kemampuan membuat argumen, membangun keterampilan dasar dan membuat inferensi pada kelas eksperimen lebih tinggi dari pada kelas kontrol, hal ini menunjukkan bahwa sistematis paparan materi dalam multimedia interaktif yang digunakan mampu memberikan kemudahan kepada siswa untuk memahami percobaan. Selain itu, animasi yang ditampilkan dan simulasi interaktif yang harus dikerjakan oleh siswa melalui lembar diskusi dapat melatih logika berpikir siswa dalam menyelsaikan permasalahan-permasalahan fisika yang berkaitan denga konsep suhu dan kalor.

Peningkatan Keterampilan Berpikir kritis pada indikator membuat inferensi yang tinggi dibandingkan dengan indikator yang lain, hal ini menunjukan bahwa paparan materi suhu dan kalor pada multimedia interaktif yang diuraikan secara runut disertai contoh soal, latihan dan tes interaktif, penugasan untuk mengerjakan soal, serta kegiatan membuat kesimpulan pada setiap lembar kerja siswa pada simulasi interaktif 
terbukti dapat berpengaruh dalam menyelsaikan masalah,

Berdasarkan hasil uji $\mathrm{t}$ diperoleh hasil bahwa terdapat perbedaan yang signifikan antara peningkatan keterampilan berpikir kritis kelas eksperimen dan kelas kontrol dengan nilai $\mathrm{t}_{\text {hitung }}=3,32>\mathrm{t}_{\text {tabel }}=1,671$, hal ini menunjukkan bahwa penggunaan multimedia interaktif lebih efektif dalam meningkatkan keterampilan berpikir kritis dari pada pembelajaran tanpa multimedia interaktif. Adanya peningkatan keterampilan berpikir kritis setelah penggunaan multimedia interaktif menunjukkan bahwa adanya pengaruh penggunaan multimedia interaktif terhadap peningkatan tersebut.

\section{Penutup}

Berdasarkan hasil penelitian dan pembahasan dapa ditarik beberapah kesimpulan sebagai berikut: (a) Penggunaan multimedia interaktif berpengaruh terhadap penguasaan konsep siswa pada materi suhu dan kalor kelas X SMA Negeri 1 Alas tahun ajaran 2013/2014. (b) Penggunaan multimedia interaktif berpengaruh terhadap keterampilan berpikir kritis siswa pada materi suhu dan kalor kelas X SMA Negeri 1 Alas tahun ajaran 2013/2014.

Agar memperoleh hasil yang lebih baik diharapkan perencanaan waktu dalam pembelajaran merupakan salah satu hal yang harus diatur secara matang oleh peneliti selanjutnya, mengingat banyak hal yang tak terduga yang dapat muncul dalam kegiatan pembelajaran.

\section{REFERENSI}

[1] Arikunto. (2006). Prosedur Penelitian (Edisi Revisi). Jakarta: PT RINEKA CIPTA.

[2] Asy'ari, Muhammad. 2013. Implementasi Model PBL (Problem Based Learning) untuk Meningkatkan Hasil Belajar dan Kemampuan Berpikr Kritis Siswa. Jurnal PRISMA. Vol 1 (1), 12-16.

[3] Depdiknas. Kurikulum 2004, Standar Kompetensi Mata Pelajaran Fisika SMA dan MA. Departemen Pendidikan Nasional. Jakarta. 2003.

[4] Exline. (2004). Workshop: Inquiry-based Learning. [Tersediaa Online] http://www.thirteen.org/edonline/concept222class inquiry/index_sub2.html. Tanggal Aksess 21 Februari 2014.

[5] Fisher, Alek. (2008). Berpikir Kritis: Sebuah Pengantar. Jakarta: Penerbit Erlanga.
[6] Gunawan. (2012). Penggunaan Simulasi Interaktif untuk Meningkatkan Penguasaan Konsep Mahasiswa pada Konsep Mekanika. Jurnal Kependidikan. Vol 2 (1), 25-30.

[7] Hasrul. 2010. Langkah-Langkah Pengembangan Pembelajaran Multimedia Interaktif. Jurnal MEDTEK. Vol 2 (1).

[8] Helperida, T. (2012), Keterampilan Berpikir Kritis. [online ]. Tersedia: http://kekeislearning.blogspot.com/2012/09/Keter ampilan-berpikir-kritis.html [ 2 Februari 2014].

[9] Helperida, T. (2012). Penguasaan Konsep. [ online ]. Tersedia: http://kekeislearning.blogspot.com/2012/09/peng uasaan-konsep.html [ 2 Februari 2014].

[10] Kartimi dan Liliasari. 2012. Pengembangan Alat Ukur Berpikir Kritis Pada Konsep Termodinamika Untuk Siswa SMA Peringkat Atas Dan Menengah. Jurnal Pendidikan IPA Indonesia. Vol 1 (1), 21-26.

[11] Mudani, Yudhi. 2012. Media Pembelajaran. Jakarta: Gaung Persada (GP) press.

[12] Redhana. 2012. Model Pembelajaran Berbasis masalah dan Pertanyaan Socratic Untuk Meningkatkan Keterampilan Berpikir Kritis Siswa. Jurnal Cakrawala Pendidikan. Vol XXXI (3), 351-356.

[13] Sanjaya. (2008). Strategi Pembelajaran Berorientasi Standar Proses Pendidikan. Jakarta: Kencana.

[14] Silaban, Bajongga. 2014. Hubungan Antara Penguasaan Konsep Fisika dan Kreativitas dengan Kemampuan Memecahkan Masalah pada Materi Pokok Listrik Statis.Jurnal Penelitian Bidang Pendidikan. Vol 20 (1), 65-75.

[15] Sodikin dkk. 2009. Jurnal Penyesuaian Dengan Modul Pembelajaran Untuk Siswa SMK Kelas X. Jurnal Teknologi Informasi. Vol 5 (2), 740-754.

[16] Subana dkk. 2000. Statistik Pendidikan. Bandung: CV Pustaka Setia.

[17] Sugiyono. 2012. Metode Penelitian Kombinasi. Bandung: Alfabeta.

[18] Sutarno. 2011. Pengunaan Multimedia Interaktif Pada Pembelajaran Medan Magnet Untuk Meningkatkan Keterampilan Berpikir Generic Sains Mahasiswa. Jurnal Exacta. Vol IX (1), 6066.

[19] Tawil, Muhammad dan suryansari kemala. 2012. Implementasi Model Pembelajaran Fisika Berbasis Portofolio Untuk Meningkatkan 
Keterampilan Berpikir Kreatif. Jurnal Pendidikan MIPA. Vol 13 (1), 1-7.

[20] Wiyono, Kentang. 2012. Peningkatan Keterampilan Berpikir Kritis Mahasiswa Calon Guru Dengan Model Mia-Piza. Forum MIPA (Majalah Ilmiah Jurusan PMIPA FKIP Unsri). Vol 14 (1), 10-16.

[21] Yulianti, Penerapan Model Pembelajaran Poe (Predict-Observe-Explain) Untuk Meningkatan Penguasaan Konsep Dan Keterampilan Berpikir
Kritis Siswa Pada Subkonsep Pencemaran Air, Tesis, Bandung.

\section{Biografi PenUlis}

Sadam Husein, S.Pd, dilahirkan di kecamatan Plampang, kabupaten Sumbawa Besar, tanggal 7 September 1991. Lulus Studi pembelajaran sekolah dasar (SD) 2004 sampai menengah atas (SMA) 2010 di kecematan plampang lulus dari Program Studi Fisika FPMIPA Institut Keguruan Ilmu Pendidikan (IKIP) mataram tahun 2014. 